\title{
Development and applications of a simulation model for vessels in the Singapore Straits ${ }^{*}$
} Xiaobo Qu, and Qiang Meng ${ }^{\dagger}$

Department of Civil and Environmental Engineering, National University of Singapore, Singapore 117576

\begin{abstract}
The traffic volume in the Singapore Strait will be significantly increased according to the prediction by the United Nations Conference on Trade and Development. Therefore, it is important for the maritime authorities (e.g. Maritime and Port Authority of Singapore) to capture a picture of ship movements in the Straits in the near future. This paper proposed a novel simulation model for ship movements in the narrow and busy shipping channel. The simulation approach is on the basis of a modified Cellular Automata model and takes interactions between consecutive ships into consideration by expert judgment from experienced personnel. Discrete event models are applied to generate vessels with different categories and velocities from four portals of the Strait. Ten ship following rules and five ship crossing rules are used to simulate the mariners' response to various navigational scenarios. The model is further verified by comparing the actual travel time through the Strait and the time derived from the model. At last, applications of the model are illustrated.
\end{abstract}

Key words: Ship Movement; the Singapore Strait; Cellular Automata Model; Discrete Event Simulation

\footnotetext{
* The earlier version of this study was presented (not for publication) at the $90^{\text {th }}$ Annual Meeting of Transportation Research Board;

† Corresponding author, Associate Professor Qiang Meng, Tel.: +65-65165494; fax +65 6779 1635; E-mail: ceemq@nus.edu.sg
} 


\section{INTRODUCTION}

The Straits of Malacca and Singapore is one of the most important shipping waterways in the world from both an economic and a strategic perspective. It is the shortest shipping channel between the Indian Ocean and the Pacific Ocean, linking major economies such as Middle East, China, Japan and South Korea. Over 300 vessels pass through the Straits on a daily basis, or around 100,000 on an annual basis, carrying $80 \%$ of the oil transported to Northeast Asia as well as one third of the world's traded goods including Chinese manufactures, Indonesian coffee, etc. The Straits is not deep enough to accommodate some of the largest ships (mostly oil tankers). At Phillips Channel, the Straits narrows to $2.8 \mathrm{~km}$ wide, with 2.1 $\mathrm{km}$ in the shipping waterways, creating one of the world's traffic chokepoints. If the Straits was blocked, nearly half of the world's fleet would be required to reroute around the Indonesian archipelago through the Lombok Strait, located between the islands of Bali and Java, or the Sunda Strait, located between Java or Sumatra, causing additional 3 days sailing time.

In order to enhance the navigational safety of vessels sailing in the Straits, as the response to the continually growing traffic volume year after year, several managerial and navigational solutions have been implemented in the Straits. The Traffic Separation Scheme (TSS) was brought into force on 1 May 1981 for safer navigation in the Straits of Malacca and Singapore (MPA, 2006). Since then, the opposing streams of traffic have been separated by the establishment of traffic lanes, which is shown in Figure 1. In 1998, the International Maritime Organization (IMO) adopted STRAITREP - the mandatory ship reporting system in the Straits of Malacca and Singapore that was proposed by the three littoral countries including Indonesia, Malaysia, and Singapore. As can be seen in Figure 1, the STRAITREP divided the Straits of Malacca and Singapore into 9 sectors so as to enhance the safety of navigation in the Straits. Sectors 7-9 (the rectangular in Figure 1) are under the authority of Singapore Vessel Traffic Services (VTS) center, which is also called the Singapore Straits, while Klang VTS and Johor VTS are the authorities of Sectors 1-5 and Sector 6, respectively. The Singapore Strait has unique hydrographic and navigational characteristics compared to the Malacca Strait, e.g. the remarkably narrower and shallower shipping lanes, characterized tide and sea current condition (peace), distinct Vessel Traffic Service system, etc. These unique features make the Singapore Strait significantly different from the Malacca Strait and the Singapore Strait is considered as the bottleneck and chokepoint of the Straits of Malacca and Singapore (MPA, 2010). 


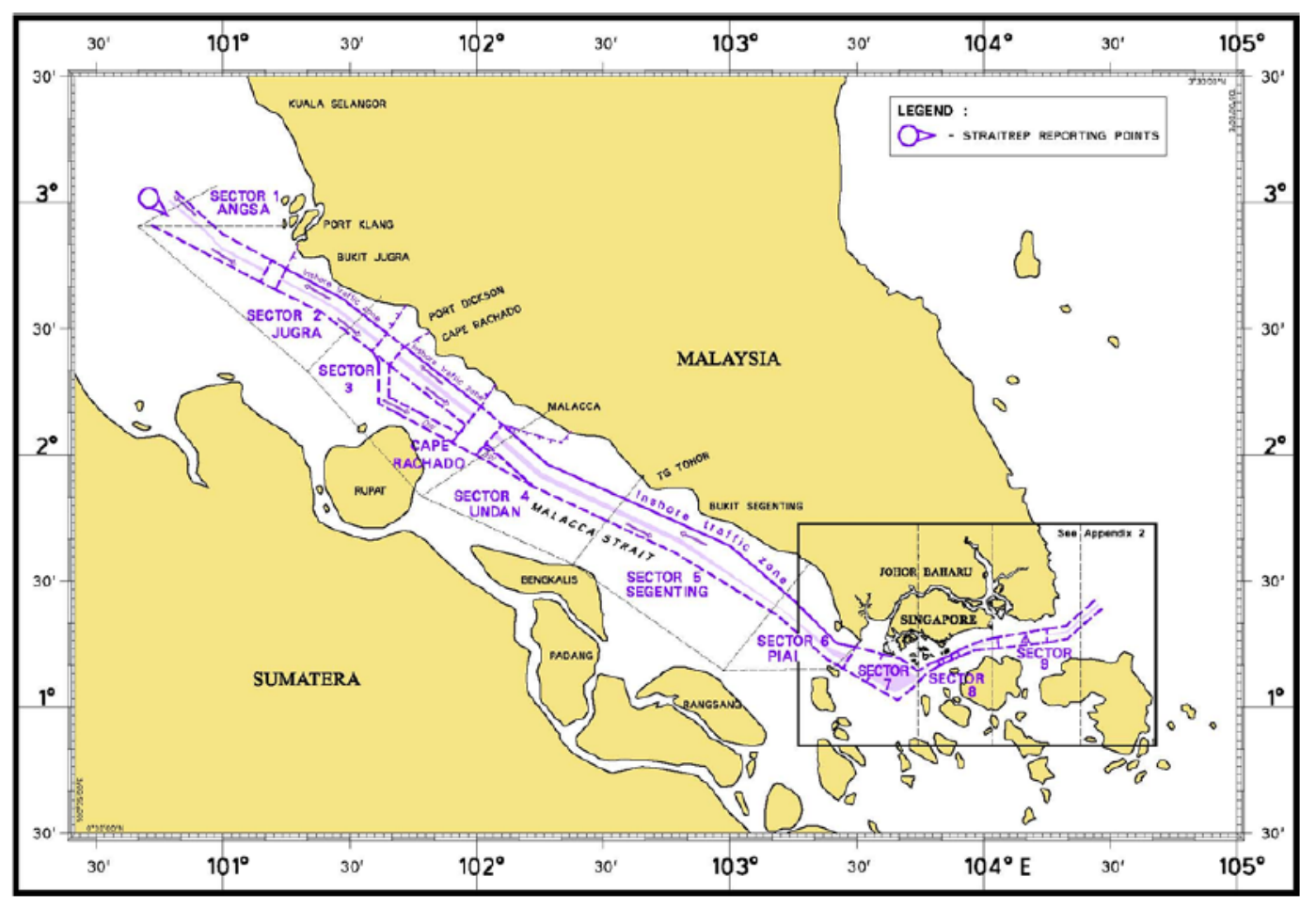

FIGURE 1 STRAITREP operational areas.

The above-mentioned two managerial and navigational solutions have uncontroversial contributions to the navigational safety of vessels in the Straits. The maritime authorities approved and implemented these solutions based on the travel survey and accident analysis. Evidently, a clear picture of the ship movements in the Straits would help maritime authorities to identify appropriate strategies so as to better manage the Straits - higher capacity, shorter passage time, and fewer accidents. However, the traffic survey and accident analysis are not easy to perform due to time and resource limits. In addition, it is not possible to get the picture of ship movements in the Straits in future when the traffic volume has been significantly increased. According to the review of maritime transport 2008 published by the United Nations Conference on Trade and Development, global maritime trade is predicted to increase by 44\% in 2020 and double by 2031 (UNCTAD, 2008). This would result in an increase of the maritime traffic volume through the Straits of Malacca and Singapore accordingly. Therefore, an approach should be proposed to attain the macroscopic parameters of ship movements in the Strait with distinct traffic flow, which facilitates authorities to make and evaluate new operational proposals. In this paper, computer simulation is used to mimic the actual situation of ship movements in the Straits. We will only perform the ship movements in the Singapore Strait due to the importance of the Section and better data availability. The simulation for the Malacca Strait can also be done similarly. 
Many researchers contributed their efforts on simulation models of ship movements. A series of studies are conducted by Turkish researchers and have been applied for the safe navigation in the Turkish Straits in the past 15 years. Some representative works are summarized as follows. Kose et al. (2003) build a discrete event simulation based model for maritime traffic in the Istanbul Strait. Ince and Topuz (2004) propose a safe navigation model design incorporating the vessels arrivals as well as the hydrodynamic force mechanisms. Mavrakis and Kontinakis (2008) propose a queueing model of maritime traffic in Bosporus Straits. The behaviors of ship captains and pilots are not taken into account in these models. The team of Tayfur Altiok takes a different approach for the narrower waterways that is of less computational time. They simply partition the waterway into slices (or cells) and take each vessel of interest and count an interaction for all other vessels in the same slice (Uluscu \& Altiok, 2009). The team led by Celik incorporates fuzzy techniques in their studies on this problem (Celik et al., 2009a; Celik et al., 2009b; Celik et al., 2009c). Recently, Szpak and Tapamo (2011) address the tracking of moving vessels in water areas based on a proposed background-subtraction model. A separate group, comprising mainly three U.S. universities: The George Washington University, Virginia Commonwealth University, and Rensselear Polytechnic Institute, develop and continuous improve their maritime transportation simulation models since the beginning of this century (Merrick \& van Dorp, 2005; van Dorp et al., 2001; van Dorp \& Merrick, 2009). In their studies, for each scenario of vessels encountering, the closest point of approach (CPA) is calculated, along with the angle of interaction and the time to the CPA. The model has been widely applied by the group to assess and/or manage the risks (e.g. the Washington State Ferries).

According to Passage Planning Guide for Malacca and Singapore Straits (2008), ship captains are warned to be extra cautious and to take necessary precautionary measures when transiting the Straits of Malacca and Singapore. It may result in unreasonable or even erroneous results if the effects of captain behaviors are disregarded in ship movement simulation models. However, the ship interactions are not systematically addressed in the above-mentioned models. Accordingly, in this study, a novel ship movement simulation model for the Singapore Strait incorporating the effects of captain behaviors and the navigational rules with respect to the Singapore Strait.

Cellular Automata (CA) models are considered as simulation models with highefficiencies that are capable of describing the complex driver behavior at roadway traffic. Many traffic flow simulation software like CELLSIM and TRANSIMS have been developed based on CA models in view of its simplicity and high computational efficiency. A CA model 
discretizes traffic lanes into a number of longitudinal cells. Vehicles move from one cell to another based on their velocities which are determined by vehicle following rules. Based on our literature review, to date, no ship movements' simulation model is developed based on CA models, which may result from two possible reasons. Firstly, different from roadway traffic being confined to vehicle traffic lanes, a ship movement may wander significantly along a predetermined sailing course. Accordingly, the velocity is not suited to be assumed as one directional like in roadway CA models. Secondly, the four vehicle following rules proposed by Nagel and Schreckenberg (1992) for roadway traffic seems over simplistic and are inadequate to simulate ship movements (Nagel \& Schreckenberg, 1992).

In this study, a CA model based ship movements model is proposed to capture the pictures of traffic movements in the Singapore Strait with different traffic volumes and vessel composition. The unique features of the Singapore Strait are taken into consideration in the proposed model. The two-dimensional velocity is used to represent the ship movements and ship interaction models based on expert judgment from ship captains are applied to simulate the responses of mariners to various navigational scenarios. The model is further verified by using the actual travel time statistics in the Strait derived from Lloyd MIU AIS ship movement database (10 July to 20 July, 2009) and the possible applications of the proposed model are also illustrated.

\section{BACKGROUND OF THE SINGAPORE STRAIT}

\subsection{Hydrographic Condition}

As shown in Figure 2, the widths of shipping legs in the Strait vary from east to west. The shipping legs of the Straits narrow to $2.1 \mathrm{~km}$ near St. John’s Island at Sector 8, with $1.6 \mathrm{~km}$ in the eastbound and only $0.5 \mathrm{~km}$ in the westbound. Average water depth in the Singapore Strait is $39.5 \mathrm{~m}$ and most places are deeper than $25 \mathrm{~m}$. However, there is still one very shallow area $\left(1^{\circ} 12^{\prime} 36^{\prime \prime} N, 103^{\circ} 53^{\prime} 10^{\prime \prime} E\right)$ in Sector 8, which endangers the ships groundings or collisions. 


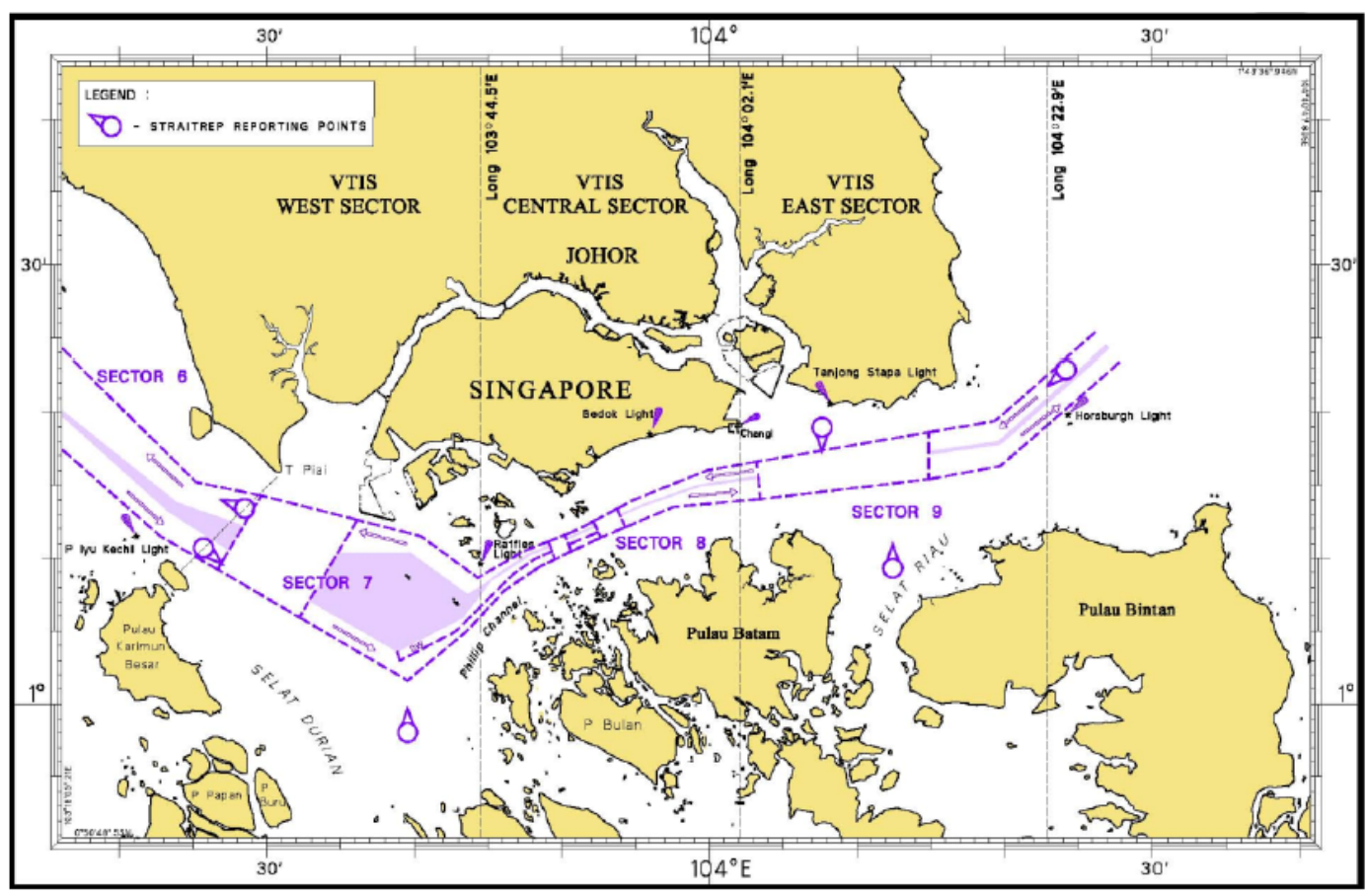

FIGURE 2 Shipping routes of the Singapore Strait.

Fog is very unusual in the Singapore Strait. However, problems do occur with smoke haze, reducing visibility to less than one mile, caused by the clearing of forests by fire on the Indonesian islands in the dry season, mainly between August and October. Additionally, heavy rain can occur at any time of the day or night and this can severely restrict visibility and, on occasion, have a detrimental effect on radar malfunction. The wind is usually low and variable, with a high percentage of calms.

The Singapore Strait experiences strong currents that are not always on the axis of the TSS. The Admiralty Tide Tables (ATT) provides rates and times for maximum streams together with the times of slack water. Table 1 shows the charted points for ATT predictions in and around the Singapore Strait.

TABLE 1 The Charted Points for ATT Predictions in and around the Singapore Strait

\begin{tabular}{lllll}
\hline Latitude & Longitude & $\begin{array}{l}\text { Current } \\
\text { Value }\end{array}$ & $\begin{array}{l}\text { East going } \\
\text { stream EBB } \\
\text { tide maxima }\end{array}$ & $\begin{array}{l}\text { East going } \\
\text { stream flood } \\
\text { tide maxima }\end{array}$ \\
\hline $1^{\circ} 06^{\prime} N$ & $103^{\circ} 44^{\prime} E$ & Nil & 3.5 knots & 2.5 knots \\
$1^{\circ} 10^{\prime} N$ & $103^{\circ} 48^{\prime} E$ & $0.3 \times 245^{\circ}$ & 1.8 knots & 1.6 knots \\
$1^{\circ} 12^{\prime} N$ & $103^{\circ} 53^{\prime} E$ & Nil & 6.2 knots & 4.0 knots \\
\hline
\end{tabular}



$1^{\circ} 20^{\prime} N$
$104^{\circ} 20^{\prime} E$
Variable
3.7 knots
2.2 knots
to 0.5 knot

In the present study, visibilities, wind, sea current, and tide are taken into account by using discrete event models, while the radar malfunction caused by rain are not considered since it is a very rare event.

\subsection{Navigational Condition}

Eighty percent of the oils transported from Persian Gulf to Northeast Asia pass through the Singapore Strait and those laden oil tankers and Very Large Crude Carrier (VLCC) need deeper draft than other categories of vessels. Therefore, a deep water route, which is highlighted in Figure 3, is designated for the eastbound deep draft vessels use. Note that there is no deep water route in the westbound since the oil tankers and VLCCs from Northeast Asia are mostly empty which do not need a deep draft. Figure 4(3) displays the westbound and eastbound with deep water route near Sentosa Island and Figure 4(4) shows the merging point of the eastbound with deep water route.

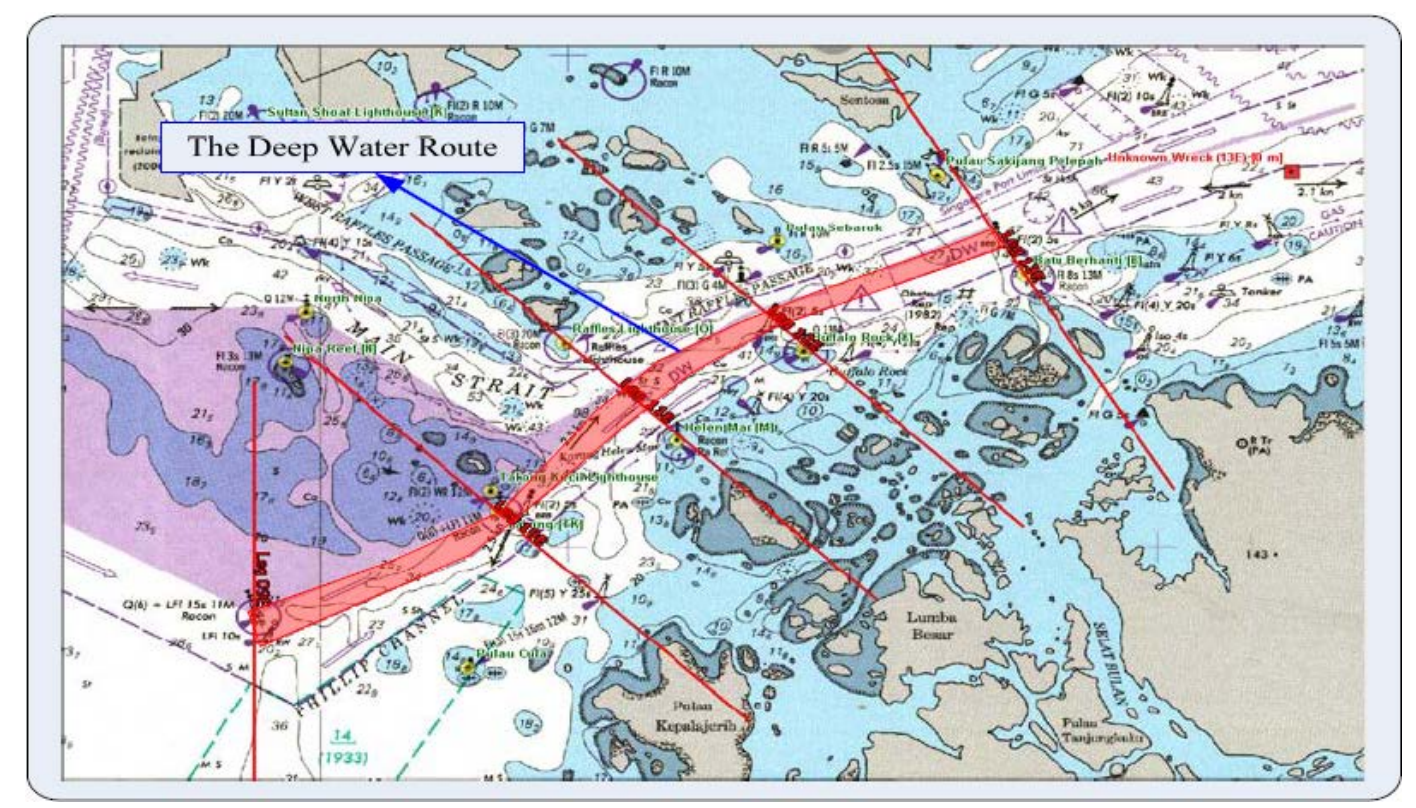

FIGURE 3 The deep water route in the Singapore Strait.

As mentioned earlier, the TSS was brought into force in 1981 for safer navigation in the Strait. Figures 4(1) and 4(2) depict the eastbound and westbound of the shipping waterway, respectively. It should be pointed out that the eastbound and westbound are further segmented 
into 8 legs and 7 legs, respectively. According to Passage Planning Guide, there is no substantial navigational, operational, and hydrographic difference in a leg. Port of Singapore and Jurong Port transship 1/5 of the world's shipping containers as the world's busiest container port (PSA, 2011). Hundreds of ships drop anchor in the harbor from the Singapore Strait to Port of Singapore or Jurong Port. As a result, there are two conflict areas, which are shown by the exclamation triangle adjacent to fairways connecting to the terminals in Figure 5. It is difficult to simulate the ship crossing interaction in the two conflict areas.

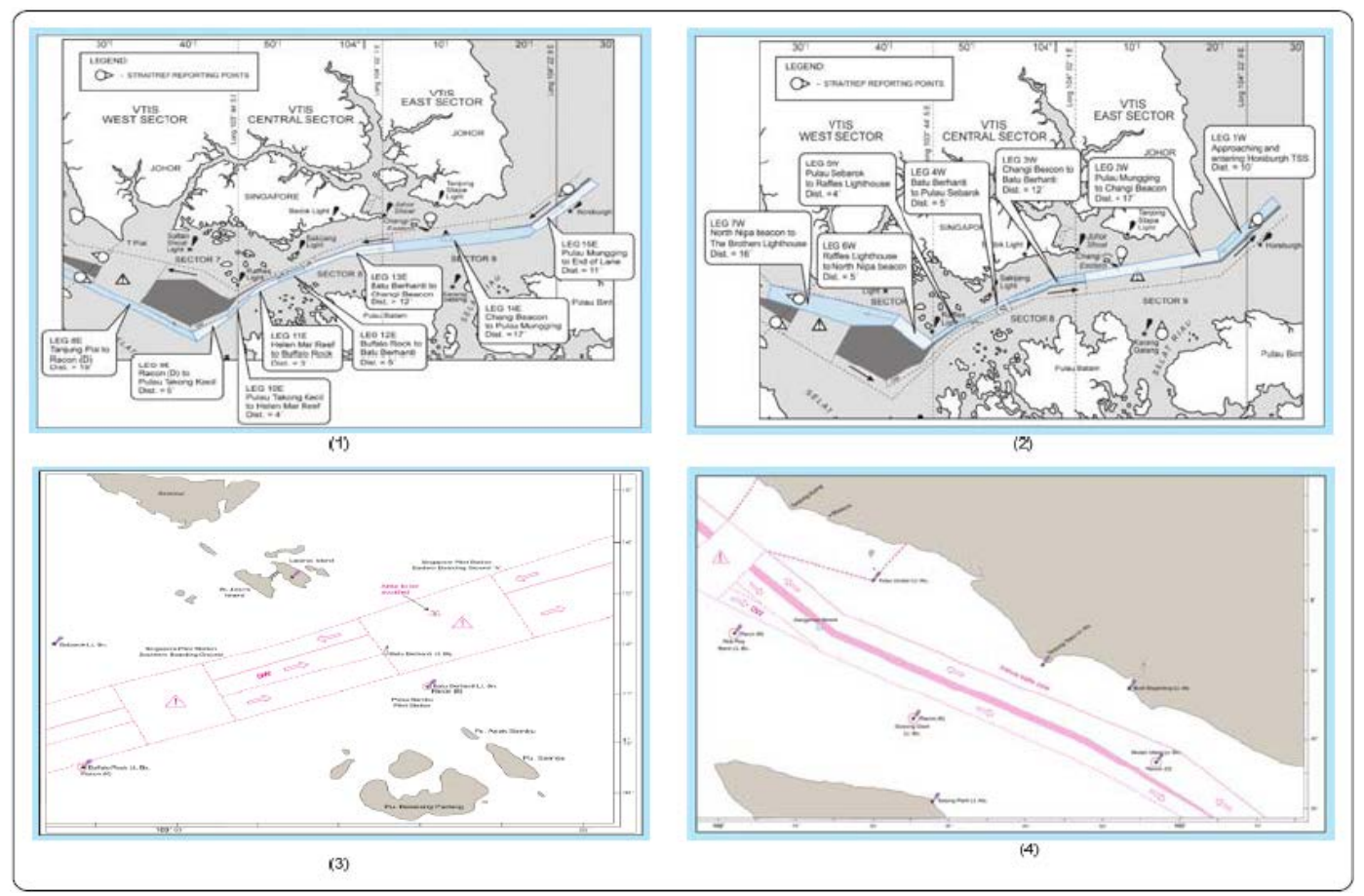

FIGURE 4 The eastbound and westbound of the Singapore Strait.

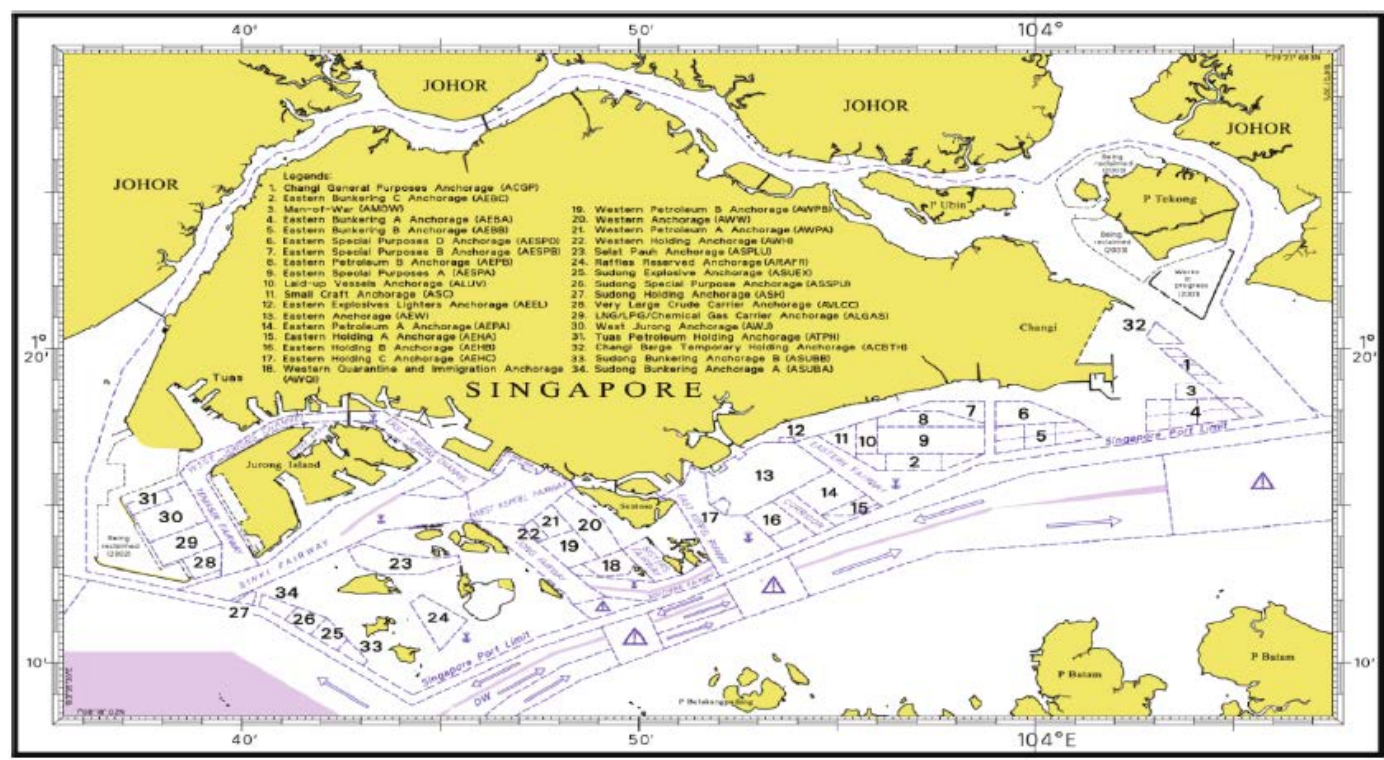


FIGURE 5 The conflict areas in the Singapore Strait.

\subsection{Traffic Condition}

In our model, the vessels passing through the Strait are categorized into four types: VLCC, tankers, container ships, and others. The VLCCs should transit though the deep water route in Sector 8. We assume that half of tankers have a draft of 15 meter or more, which will also sail in the deep water routes. The number of ships passed through the Strait from 2002 to 2007 is summarized in Table 2. The vessel parameters with various categories are summarized in Table 3.

TABLE 2 Distribution of Various Categories of Vessels Passing through the Singapore Strait

\begin{tabular}{lcccccc}
\hline Vessel Type & 2002 & 2003 & 2004 & 2005 & 2006 & 2007 \\
\hline VLCC & 3,301 & 3,487 & 3,477 & 3,788 & 3,851 & 3,753 \\
Tanker & 14,591 & 15,667 & 16,403 & 14,759 & 14,784 & 14,931 \\
Containership & 20,091 & 19,575 & 20,187 & 20,818 & 22,615 & 23,736 \\
Others & 22,051 & 23,605 & 23,569 & 23,256 & 24,399 & 28,298 \\
\hline
\end{tabular}

TABLE 3 Vessel Parameters with Various Categories

\begin{tabular}{lllll}
\hline Class & Length & Beam & Draft & Maximum speeds \\
\hline VLCC & $470 \mathrm{~m}$ & $60 \mathrm{~m}$ & $20 \mathrm{~m}$ & About 16 knots \\
Tanker & $300 \mathrm{~m}$ & $47 \mathrm{~m}$ & $16 \mathrm{~m}$ & About 19 knots \\
Container Ship & $280-360 \mathrm{~m}$ & 60 & $15 \mathrm{~m}$ & $9 \sim 25$ knots \\
Others & $200-300 \mathrm{~m}$ & $29-50 \mathrm{~m}$ & $15 \mathrm{~m}$ & $16 \sim 28$ knots \\
\hline
\end{tabular}

\subsection{Rules and Regulations}

Several rules are made for vessels navigating through the Straits of Malacca and Singapore. We list the rules with respect to speed limit and deep water routes as below, which are critical for our model.

According to Rules for Vessels Navigating through the Straits of Malacca and Singapore, vessels navigating in Leg 3W, Leg 4W, Leg 5W, Leg 6W, Leg 8E, Leg 9E, Leg $10 \mathrm{E}$, Leg 11E, and Leg $12 \mathrm{E}$ of the Strait, as far as it is safe and practicable, proceed at a 
sailing speed of not more than 12 knots over the ground. Deep draught vessels having a draft of 15 meters or more and VLCCs of 150,000 dwt and above shall allow for an under keel clearance of at least 3.5 meters at all times during the entire passage through the Singapore Strait. Eastbound deep draft vessels shall use designated deep water routes. Eastbound deep draft vessels navigating in the deep water routes in Phillip Channel and Singapore Strait shall, as far as practicable, avoid overtaking.

\section{MODEL DEVELOPMENT}

\subsection{Procedure}

A ship movement simulation model should have four elements: ship, speed, location, and time, namely, the location and speed of a ship at any examining time. The CA model in roadway transportation is defined on a one-dimensional array of $L$ cells and with open or periodic boundary conditions. Each cell may either be occupied by one vehicle, or it may be empty. Each vehicle has an integer velocity with values between zero and $v_{\max }$ in terms of the unit cell/second. Discrete event models such as Monte Carlo sampling simulation are used to generate the vehicles that enter the road and vehicle following rules determines the driver acceleration/deceleration behaviors. Note that a vessel should sail along a predetermined course when it passes through the Strait. However, the vessel may wander around the course due to the complexity of maritime transportation caused by tide, sea current, wind, etc. In order to mimic the ship movements around the predetermined course due to maneuvering and/or external causations, the velocity of a vessel should be decomposed into two components, one direction along the predetermined course and the other direction perpendicular to the predetermined course, at any time. As shown in Figure 6, $V_{x}$ stands for the velocity along the predetermined course and $V_{y}$ represents the velocity of the direction perpendicular to the course. 


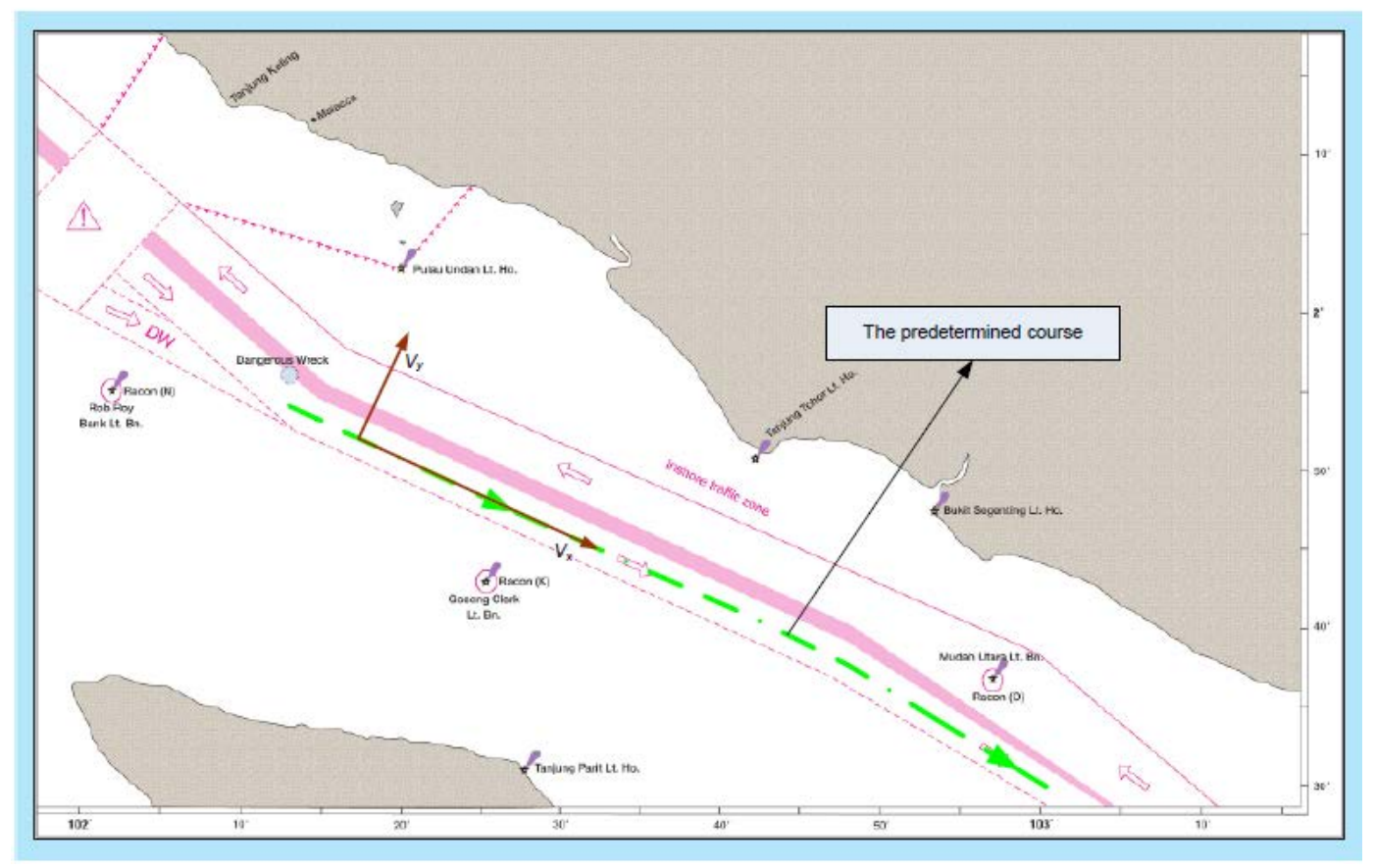

FIGURE 6 The velocity decomposition.

The proposed simulation procedure is as follows.

Step 0: determine the simulation duration $T$;

Step 1: divide the strait into a number of cells based on cellularization principle in the section of Cell determination;

Step 2: apply discrete event models to generate ships beside the entries of the strait in the duration between time 0 to time $T$ and the generated ships enter into the strait;

Step 3: check the speeds and locations of all the ships in the strait at time $t_{i}$;

Step 4: update the speeds of all ships in the strait at time $t_{i}$ based on ship interaction models in the section of Ship Interaction Models;

Step 5: update the locations of all ships in the strait at time $t_{i+1}$ based on the speeds of ships;

Step 6: check whether $t_{i+1}$ is greater than $T$ : if so, simulation stops; otherwise, go to step 3.

\subsection{Cell Determination}

In a CA model, the traffic route is cellurized into a number of cells. A vehicle or ship may occupy several cells and it will move from cells to cells based on its velocity in terms of cell/min. The length and width of cell could be user-defined. In this model, the width of cells is determined to be $60 \mathrm{~m}$ since the beams of ships are mainly less than $60 \mathrm{~m}$ based on statistics 
in Table 3. The length of cells could be determined according to expert judgment based on a compromise between accuracy and computational complexity. In this study, the length of cells is determined to be 30 meters. It is 1400-cell long in horizontal direction from South China Sea to the Strait of Malacca. Note that the number of cells in vertical direction changes along the Strait. Vessels with different categories may occupy 8 to 16 cells in the Strait.

\subsection{Discrete Event Models}

A discrete event simulation model is developed to generate the vessels entering the strait. The flowchart of the simulation process is shown in Figure 8. The distributions of vessels arrival are assumed to follow Poisson distributions based on statistics. Therefore, the time intervals between two consecutive ships are assumed to be exponentially distributed. In the Singapore Strait, we assume that there are four ship generating point: the portal of westbound, the portal of eastbound, Jurong Port, and Port of Singapore. The destination in Figure 7 means the place which vessels sail to when leaving the Singapore Strait. For example, for a vessel in eastbound, the possible destinations are Jurong Port, Port of Singapore, and the exit of eastbound. The distribution of destinations and ship composition are assumed to follow discrete distributions. According to Table 2, the vessel velocities may vary particular ranges. Therefore, we randomly generate the velocities for each vessel by using a uniform distribution. In addition, the tide, sea current, and wind differ from one place to another in the Strait and normal distributions are used to generate the tide, sea current, visibilities, and wind condition based on their actual conditions. 


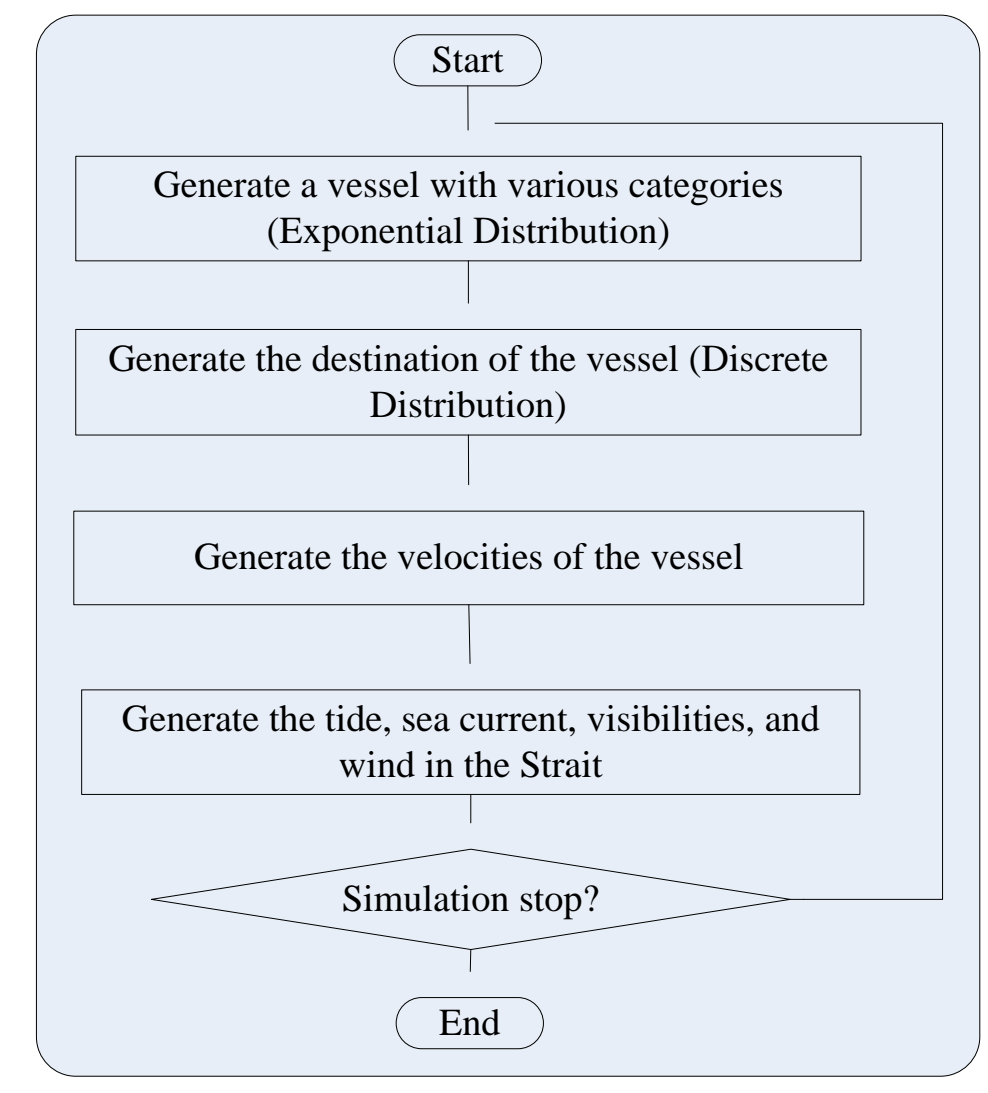

FIGURE 7 Flowchart of discrete event models.

\subsection{Ship Interaction Models}

van Dorp and Merrick (2009) proposed a ship interaction model based on Closest Point of Approach type arguments. In the paper, the authors pointed out that the critical headways, between two consecutive ships, in terms of distance and time were half a nautical mile and five minutes, respectively. Note that the speed limits in most sectors of the Strait are 12 knots. In this interaction model, we apply headways in terms of time to update the vessel speeds.

The ship-following rules and ship-crossing rules are derived from expert judgment and the interviews to captains. They are applied to simulate the decisions of mariners' responses to various navigational scenarios. In a CA model, the speeds should be integer in terms of cell/min. However, in the discrete event simulations, some speeds are uniformly or normally distributed, which result in non-integer speed values. Accordingly, in view of conservative safety requirements, the program will compute the ceilings of the speeds (the smallest integer not less than the speeds) derived from the rules as the speeds in the ship movement model. The error becomes smaller if the Straits is further divided into smaller cells.

The impact of tide, sea current, and wind are formulated by random variables. In this study, normal distributions are used to represent the impact of these parameters on speed. 
Normal distributions are capable of formulating the randomness and dynamic property of these parameters. In reality, these two terms may also be assumed to follow other distributions if the data are available. In this study, by using the limited data in Table 1, we assume that $\varepsilon_{x}$ and $\varepsilon_{y}$ follow normal distribution with mean 0 and variance 1 knots in the following applications. The generated $\varepsilon_{x}$ and $\varepsilon_{y}$ are used to update vessels' speed based on the ship following and crossing rules at every minute (we update the ship speed minute by minute), namely, at every time that the discrete event generated, an additional speed is added to the vessels' speed to reflect the impact of tide, sea current, and wind on vessels.

\subsubsection{Ship following rules for the vessels in the Strait}

For the maritime cellular automata model, we defined 10 ship following rules with different priorities. These rules control all ships entering the waterway or fairway and determine their shipping pattern, namely, the way how $V_{x}$ and $V_{y}$ changes.

The ship-following rules are as follows ordered in terms of priorities.

Rule 1: If a vessel moves along the predetermined course, then $V_{x}=V_{x}+\varepsilon_{x}, V_{y}=\varepsilon_{y}$, where $\varepsilon_{x}$ and $\varepsilon_{y}$ are random variables determined by tide, sea current, and wind around the vessel;

Rule 2: If a vessel is approaching the precautionary areas (e.g., 100 cells ahead), then $V_{x}=V_{x}-2+\varepsilon_{x}, V_{y}=V_{y}+2+\varepsilon_{y}$, the direction of $V_{y}$ is towards the right side of the sailing direction;

Rule 3: If an oil tanker or VLCC is sailing in the deep water route and the distance from the vessel ahead is less than $L$ (e.g., 100 cells), then $V_{x}=V_{x}-3+\varepsilon_{x}, V_{y}=V_{y}+\varepsilon_{y}$;

Rule 4: If a vessel (not a deep draft vessel) is sailing in waterways other than the deep water routes and the distance from the vessel ahead is less than $L$ (e.g., 60 cells), then $V_{x}=V_{x}+\varepsilon_{x}, V_{y}=V_{y}+3+\varepsilon_{y}$, the direction is toward the right side of the sailing direction;

Rule 5: If the visibility condition is poor and vessel velocity is greater than 8 cells/min, then $V_{x}=V_{x}-1+\varepsilon_{x}, V_{y}=V_{y}+\varepsilon_{y}$;

Rule 6: If the velocity composition is greater than the velocity limit of the area, $V_{x}=V_{x}-2+\varepsilon_{x}$ and $V_{y}=V_{y}-2+\varepsilon_{y}$;

Rule 7: If the ship drifts off the predetermined course, then $V_{x}=V_{x}-1+\varepsilon_{x}$, $V_{y}=V_{y}+1+\varepsilon_{y}$, the direction is towards the predetermined course; 
Rule 8: If the distance between two consecutive vessels is greater than 200 cells and the vessel velocity is less than 8 cells/min, then $V_{x}=V_{x}+1+\varepsilon_{x}$;

Rule 9: If the distance from the fairway ahead is less than $L$ (e.g., 70 cells), then $V_{x}=V_{x}+2+\varepsilon_{x}, V_{y}=V_{y}+\varepsilon_{y}$;

Rule 10: If a vessel (not sailing in deep draft water) is about to overtake, then $V_{y}=V_{y}-1+\varepsilon_{y}, V_{x}=V_{x}+\varepsilon_{x}$ the direction is that of increasing the gap from either star board or port side of the overtaken vessel.

\subsubsection{Ship crossing rules for the ships being about to enter the Strait from fairways}

The ship crossing rules are applied to the ships which are about to call at a port and the ships sailing from the Port of Singapore or Jurong Port. Note that we assume deep draft vessels will not stop at Jurong port or Port of Singapore.

Rule 1: If a vessel, which is about to call at a port, is approaching the fairway ahead, then $V_{x}=V_{x}-1+\varepsilon_{x}$

Rule 2: If a vessel in westbound, which is about to call at a port, arrives at the fairway, then $V_{y}=V_{x}-1+\varepsilon_{x}, V_{x}=\varepsilon_{x}$, the direction of $V_{y}$ is towards the port;

Rule 3: When a vessel in eastbound, which is about to call at a port, arrives at the fairway, if the distance between two of its neighboring vessels in the westbound is great than $L$ (e.g. 100 cells), then $V_{y}=V_{x}-1+\varepsilon_{x}, V_{x}=\varepsilon_{x}$, the direction of $V_{y}$ is towards the port;

Rule 4: If a vessel, which is about to enter the westbound from a fairway, is approaching the Strait, then $V_{x}=V_{x}-5+\varepsilon_{x}, V_{y}=V_{y}+5+\varepsilon_{y}$ (note: vessels will turn here);

Rule 5: When a vessel, which is about to enter the eastbound from a fairway, if the distance between two of its neighboring vessels in the westbound is great than $L$ (e.g. 100 cells), then $V_{x}=V_{x}+1+\varepsilon_{x}, V_{y}=V_{y}+\varepsilon_{y}$

\section{MODEL VERIFICATION AND APPLICATION}

\subsection{Model Verification}

The outputs of the model include the entry times, categories, lengths, beams, locations (latitude and longitude), longitudinal and vertical speeds, and directions of various ships in 
the Strait in a set of discrete time points (minute by minute). Accordingly, visualizations of ship movements can be realized.

The sea current, tide, and wind condition obtained from Passage Planning Guide for Malacca \& Singapore Straits, the navigational and hydrographic condition in the second section of this paper, and the traffic volume and composition from Table 2 are utilized to perform the traffic simulation for the Singapore Strait at present. In order to verify the accuracy of the simulation model, mean and standard deviation (Std) of travel times for vessels with various categories are used as the key indicator for comparisons against the actual data in the Singapore Strait derived from Lloyd MIU ship movement database (July 10 to July 20, 2009). We spent around 5 hours to perform 'one month' movement simulation runs using the proposed model. The travel times for various categories of vessels and actual historical travel times are summarized in Table 4.

TABLE 4 Comparisons between the Actual Travel Time and the Travel time Derived from the Model

\begin{tabular}{|c|c|c|c|c|c|c|}
\hline \multirow[t]{2}{*}{ Vessel Type } & \multirow[t]{2}{*}{ Direction } & \multicolumn{2}{|c|}{$\begin{array}{l}\text { Travel Time } \\
\text { in minutes } \\
\text { (Historical) }\end{array}$} & \multicolumn{2}{|c|}{$\begin{array}{l}\text { Travel Time } \\
\text { in minutes } \\
\text { (Simulation) }\end{array}$} & \multirow[t]{2}{*}{$\begin{array}{c}\text { Relative error } \\
\text { in terms of } \\
\text { mean passage time }\end{array}$} \\
\hline & & Mean & Std & Mean & Std & \\
\hline VLCC & Westbound & 452 & 101 & 383 & 73 & $15.27 \%$ \\
\hline VLCC & Eastbound & 485 & 107 & 397 & 81 & 18.14 \\
\hline Tanker & Westbound & 431 & 119 & 434 & 87 & $0.70 \%$ \\
\hline Tanker & Eastbound & 472 & 121 & 438 & 62 & $7.20 \%$ \\
\hline Containership & Westbound & 349 & 117 & 357 & 91 & $2.29 \%$ \\
\hline Containership & Eastbound & 343 & 124 & 351 & 71 & $2.33 \%$ \\
\hline Others & Westbound & 430 & 142 & 407 & 77 & $5.35 \%$ \\
\hline Others & Eastbound & 467 & 137 & 486 & 69 & $4.07 \%$ \\
\hline
\end{tabular}

From Table 4, the relative errors for tankers, containerships and others are less than $6.50 \%$, which are within a reasonable range. However, the relative error of VLCC is much higher. This may be because some captains of VLCCs in the Strait are far too cautious so that the VLCCs sails with a speed less than that shown in Passage Planning Guide for Malacca and Singapore Straits. In addition, we find two other interesting findings. Firstly, the travel times derived from the simulation model are consistently less than the actual travel times. This implies that some minor factors which may affect the travel time are not taken into consideration in our simulation model and the simulation results are over optimistic. Secondly, the vessels in the eastbound spend more time to pass through the Strait than those in the westbound, which is possibly due to the imbalance of traffic volume and vessel mix. 
In addition, in order to further verify the model, the speed histograms of passage times with various categories are considered as another measure for verification purposes. This measure provides a relatively microscopic measure to validate the model. From the Lloyd MIU ship movement database (July 10 to July 20, 2009), there are totally 376 vessels (24 VLCCs, 75 tankers, 131 container ships, and 146 other types of ships) and 294 vessels (16 VLCCs, 45 tankers, 122 container ships, and 111 other types of ships) transiting through the westbound and eastbound respectively. The actual passage time of every individual transiting ship can be derived from the ship movement database vessel by vessel. The passage time for each transiting ship can also be generated from the proposed simulation model. The speed histograms for VLCC and container ships are shown in Figure 8. The two datasets have no statistically difference given the significance level of 0.1 .

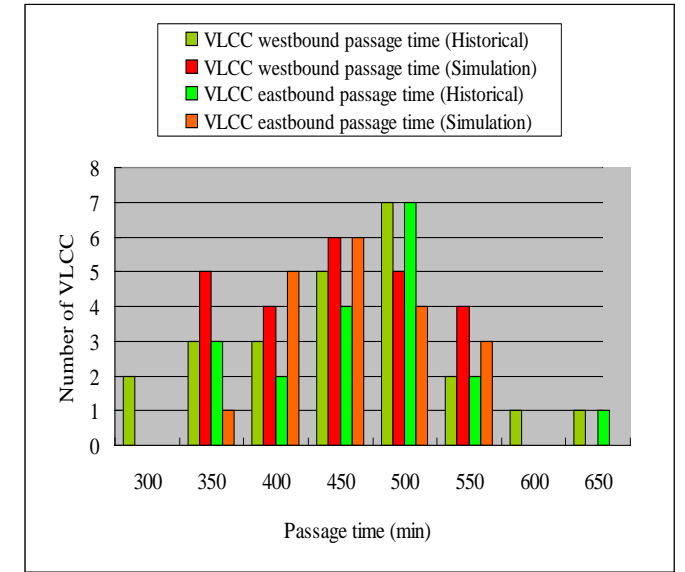

(a)

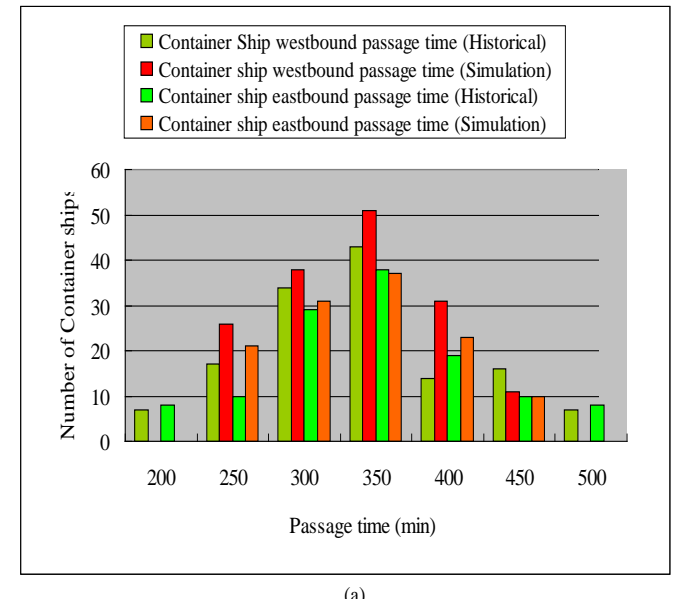

(a)

FIGURE 8 Speed histograms of passage times (VLCC and Containership).

\subsection{Model Applications}

The travel time with different traffic volumes can be easily estimated based on a simulation model. We can simply adjust the parameters of discrete event models and get the average travel time with respect to different traffic volumes. As can be seen in Table 4, the average travel time with the current traffic volume is 395.6 minutes. As mentioned above, global maritime trade is predicted to increase by 44\% in 2020 and double by 2031. Accordingly, we run simulations for the traffic volume in 2020 and 2031 using the forecasting traffic volumes. The average travel times in 2020 and 2031 are 432.9 minutes and 450.4 minutes, respectively.

Frequency estimation plays an essential role in risk assessment procedure, which is to predict the number of collisions per year in a specific water area. Based on the literature, three 
types of approaches are proposed by various scholars, namely, mathematical model, ship domain analysis, and fault tree analysis.

The basic idea of applying mathematical model to estimate frequency is to apply the Newton Laws of Motion to predict the courses of vessels under various scenarios (Kaneko, 2004; Pedersen, 2010). The faster the speed of a vessel is, the closer two vessels are, the potentials of collisions are higher. Evidently, the ship velocities, ship locations, the courses over ground (COG) of the two ships, etc. are the most important contributing factors to the ship collision. These parameters can be generated by using the proposed simulation models. Therefore, the model is capable of predicting the number of collision when the traffic flow increases in future.

Another possible application is to provide maritime authorities the forecasting data about ship movements to support their decisions such as whether or not to introduce new navigational facilities and/or making new regulations. For example, as the increase of the traffic volume, ship entry control, which has already been implemented in the Istanbul Strait (Kose et al., 2003), is possible to be put in practice. The model could also simulate scenarios when the entry control is implemented.

\section{CONCLUSIONS AND LIMITATIONS}

This paper proposed a CA model based simulation approach for the Singapore Strait which takes the unique features of the Strait into consideration. Discrete event models are applied to generate vessels with different categories and velocities from four portals of the Straits. 10 ship following rules and 5 ship crossing rules, which are derived from expert judgment and the interviews to ship captains, are used to simulate the mariners' response to various navigational scenarios. The model is further verified by comparing the actual travel time and that derived from the model. Finally, some possible applications of the model are also illustrated.

There are two limitations in this study. Firstly, the accuracy of the model highly depends on the ship interaction model based on ship captains' judgment and the model needs further validation based on actual data. Secondly, the discrete event models may not perfectly reflect the actual condition in the Straits, especially the impact of tide, sea current, visibility, and other complex traffic conditions. 
This paper is supported by the research project "Development of QRA model and software for shipping operations in the Straits of Malacca and Singapore” funded by Maritime Innovation and Technology Fund.

\section{REFERENCES}

Celik, M., Cebi, S., Kahraman, C., \& Er, I.D. (2009a). Application of axiomatic design and TOPSIS methodologies under fuzzy environment for proposing competitive strategies on Turkish container ports in maritime transportation network. Expert Systems with Applications. 36: 4541-4557.

Celik, M., Er, I.D., \& Ozok, A.F. (2009b). Application of fuzzy extended AHP methodology on shipping registry selection: The case of Turkish maritime industry. Expert Systems with Applications. 36: 190-198.

Celik, M., Kahraman, C., Cebi, S., \& Er, I.D. (2009c). Fuzzy axiomatic design-based performance evaluation model for docking facilities in shipbuilding industry: The case of Turkish shipyards. Expert Systems with Applications. 36: 599-615.

Ince, A.N., \& Topuz, E., (2004). Modelling and simulation for safe and efficient navigation in narrow waterways. Journal of Navigation. 57: 53-71.

Kaneko, F., (2004). Methods for Probabilistic Safety Assessments of Ships. Journal of Marine Science and Technology, 7: 1-16.

Kose, E., Basar, E., Demirci, E., Guneroglu, A., \& Erkebay, S., (2003). Simulation of Marine Traffic in Istanbul Straits. Simulation Modelling Practice and Theory. 11: 597-608.

Maritime and Port Authority of Singapore. (2006) Safety of Navigation in the Singapore Strait.

http://www.mpa.gov.sg/sites/circulars_and_notices/pdfs/port_marine_circulars/pc0620.pdf Accessed on 19 July 2010.

Maritime and Port Authority of Singapore. Carriage Capacity of the Straits of Malacca and Singapore. Presented at Maritime Challenges and Priorities in Asia. 20-21 Jan 2010. Singapore.

Mavrakis D., \& Kontinakis, N., (2008). A queueing model of maritime traffic in Bosporus Strait. Simulation Modelling Practice and Theory, 16: 315-328.

Merrick, J.R.W, \& van Dorp, J. R., (2005). Assessing uncertainty in simulation-based maritime risk assessment. Risk Analysis, 25: 731-743.

Nagel, K. \& Schreckenberg, M. (1992). A Cellular Automaton Model for Freeway Traffic. Physics I 2: 2221-2229. 
Passage Planning Guide: Malacca \& Singapore Straits (2nd Edition 2008). Published by Witherby Seamanship International Ltd. 2008.

Pedersen, P.T. (2010). Review and application of ship collision and grounding analysis procedures. Marine Structures. 23: 241-262.

PSA Singapore Terminals. http://www.portnet.com/pdf/061010-national-it-award.pdf Accessed on 19 May 2011.

Szpak, Z.L., \& Tapamo, J.R. (2011). Maritime surveillance: Tracking ships inside a dynamic background using a fast level-set. Expert Systems with Applications. 38: 6669-6680.

Uluscu, O.S., \& Altiok, T., (2009). Waiting time approximation in single-class queueing systems with multiple types of interruptions: modelling congestion at waterways entrances. Annals of Operations Research. 172: 291-313.

UNCTAD. (2008) Review of Maritime Transport 2008. http://www.unctad.org/Templates/WebFlyer.asp?intItemID=4659\&lang=1 Accessed on 19 May 2011.

van Dorp, J. R.,Merrick, J., Harrald, J., Mazzuchi, T., \& Grabowski, M. (2001). A risk management procedure for the Washington State ferries. Risk Analysis, 21: 127-142. van Dorp, J.R., \& Merrick, J.R.W., (2009). On a risk management analysis of oil spill risk using maritime transportation system simulation. Annals of Operations Research. DOI: 10.1007/s10479-009-0678-1. 